\title{
THE IMPACT OF THE TRADITIONAL OWN RESOURCES ON THE BUDGET OF THE EUROPEAN UNION
}

\author{
ANNA REIWER-KALISZEWSKA ${ }^{1}$
}

\begin{abstract}
Traditional own resources are a part of a broader category of European Union revenues - the own resources. The own resources category consists of three types of resources: traditional own resources, which mainly consist of customs duties on imports from outside the European Union and sugar levies, own resources based on value-added tax (VAT) and own resources based on GNI - gross national income (each Member State transfers a standard percentage of its GNI to the EU), which serves as the balancing resource. Currently, the types of own resources and the methods for calculating them have been set by Council in a decision of 26 May 2014 on the system of own resources of the European Union. Changes were introduced to the system of the own resources for the period 2014-2020. The decision has entered into force on 1 October 2016, however, the rules apply retroactively as of 1 January 2014. The aim of this article is to analyze the issue of traditional own resources (a part of a broader category of resources - the own resources) and its impact on the budget of the European Union.
\end{abstract}

\section{Keywords}

Law; customs; trade defense instruments; anti-dumping; anti-subsidy

\section{JEL Classification: F13, F19, G18}

\section{Introduction}

The issues concerning the budget of the European Union have been placed in the Treaty on the Functioning of the European Union. According to art. 311 of TFUE

1 Doctor, Department of Financial Law, Faculty of Law, University of Business and Administration in Gdynia, Poland. The author specializes in tax and customs law, especially in the issues concerned with the trade defense instruments. She is the author and co-author of numerous books and articles published in prestigious journals. Contact email: areiwer@yahoo.co.uk. 
the European Union shall provide itself with the means necessary to attain its objectives and carry through its policies. Without prejudice to other revenue, the budget shall be financed wholly from own resources.

The Council, acting in accordance with a special legislative procedure, shall unanimously and after consulting the European Parliament adopt a decision laying down the provisions relating to the system of own resources of the Union. In this context, it may establish new categories of own resources or abolish an existing category. That decision shall not enter into force until it is approved by the Member States in accordance with their respective constitutional requirements. The Council, acting by means of regulations in accordance with a special legislative procedure, shall lay down implementing measures for the Union' own resources system. The Council shall act after obtaining the consent of the European Parliament. Currently, the types of own resources and the methods for calculating them have been set by Council in a decision of 26 May 2014 on the system of own resources of the European Union.

The aim of this article is to analyze the issue of traditional own resources (a part of a broader category of resources - the own resources) and to confirm or disprove the main hypothesis, that although they have a huge impact on the budget of the European Union the long-term trend in traditional resources is downwards. This article aims to present the evolution of traditional own resources in the European Union and the assessment of their development. Method used are the analysis and the synthesis.

\section{Own Resources System}

The own resources category consists of three types of resources: traditional own resources, which mainly consist of customs duties on imports from outside the European Union and sugar levies, own resources based on value-added tax (VAT) and own resources based on GNI - gross national income (each Member State transfers a standard percentage of its GNI to the EU), which serves as the balancing resource. The Union's own resources are collected by the Member States in accordance with the national provisions imposed by law, regulation or administrative action. These provisions should be adapted to meet the requirements of Union rules.

Between 1958 and 1970 the European Union, similarly to other international organizations, was exclusively financed by member-states contributions (Van der Hoek, 2005: 268). The system of the own resources was introduced on 21 April 1970. The system initially contained 3 different revenue sources. The first own resource - levies on agricultural and sugar trade was introduced in 1971. Customs 
The Impact of the Traditional Own Resources on the Budget of the European Union

duties on trade with third countries were added between 1971 and 1975. The own resource based on value added tax was added in 1979. Due to growing budget expenditures, it was gaining an increasing share of the contribution structure (this led to an increase in the rate of VAT payments). In the 80's, traditional own resources began to decline, and that was why the own resources based on GNP (gross national product) were introduced.

In the beginning, the own resources based on GNI (gross national income) were designed to cover the balance of total expenditure not covered by the other own resources. However later in the following years, the share of VAT payments began to decline gradually, and at the same time, the contribution from gross national product increased. In 2002, the GNP-based measure was converted to GNI payments. The current funding system provides a smooth, stable financing of the EU budget, as any deficiencies are supplemented by GNI.

\section{Figure 1 EU Budget Revenues from 1970 till 30 November 2016 in EUR million}

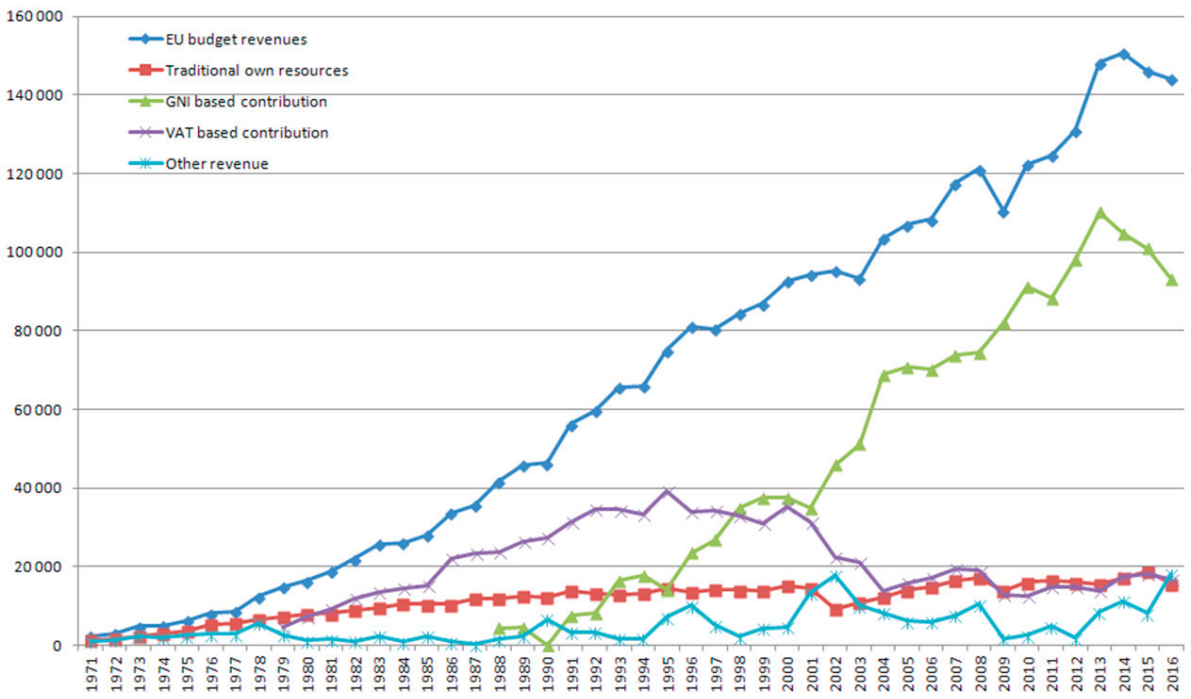

Source: Annual accounts of the European Union for years 1971 to 2015, excl. revenues from exchange transactions, i.e. financial income and other. Data for the year 2016 includes figures for the period ending 30 November 2016. www.eu.europa.eu/budget/figures/index_en.cfm, accessed 6 June 2017.

Nowadays most revenues come from GNI based contributions (Figure 2). Member States contribute according to their Gross National Income. However, this basis is straightforward as there are some adjustments to the payments as a result of negotiation. In order to correct excessive contribution by certain countries, 
correction mechanisms have been designed. First of all, The United Kingdom is reimbursed by $66 \%$ of the difference between its contribution and the amount it receives back from the EU budget. Additionally, over the current period (20142020) Denmark, the Netherlands and Sweden have secured reductions to their GNI based contribution.

The second significant source of revenue of the European Union is VAT-based contributions. VAT based contributions are based on a harmonized measure of consumer spending and thus have little to do with actual VAT payments. This is because different countries have different rates, and over time they have not been harmonized. As indicated above the share of VAT based contributions has been declining and now estimates for about 13\% of the EU budget revenue (Figure 2).

Traditional own resources consist of levies, premiums, additional or compensatory amounts, additional amounts or factors, Common Customs Tariff duties and other duties established or to be established by the institutions of the Union in respect of trade with third countries, customs duties on products under the expired Treaty establishing the European Coal and Steel Community, as well as contributions and other duties provided for within the framework of the common organization of the markets in sugar. Traditional own resources make up about 13\% of the EU budget.

There are also revenues other than own resources which include tax and other deductions from European Union staff remunerations, contributions from non-EU countries to certain programs (e.g. in research), interests on late payments and fines and other diverse items. If there is a surplus at the end of the year, the difference in the form of reduced contributions the following year is returned to the Member States.

Figure 2 EU Budget Revenue in EUR Million from 2009 till 2016

\begin{tabular}{|l|c|c|c|c|c|c|c|c||}
\hline $\begin{array}{l}\text { Own resources and } \\
\text { contributions revenue } \\
\text { (note 3.1 to annual } \\
\text { accounts) }\end{array}$ & 2009 & 2010 & 2011 & 2012 & 2013 & 2014 & 2015 & 2016 \\
\hline GNI based contribution & 81978 & 91178 & 88442 & 98061 & 110194 & 104688 & 100967 & 93367 \\
\hline VAT based contribution & 12795 & 12517 & 14763 & 14871 & 14019 & 17462 & 18087 & 16936 \\
\hline Traditional own resources & 14002 & 16065 & 16528 & 16087 & 15467 & 17137 & 18730 & 15703 \\
\hline $\begin{array}{l}\text { Other revenue (excl. } \\
\text { corrections) }\end{array}$ & 1762 & 2568 & 4944 & 1900 & 8579 & 11338 & 8243 & 18187 \\
\hline Total revenue & 110537 & 122328 & 124677 & 130919 & 148259 & 150625 & 146027 & 144193 \\
\hline
\end{tabular}

Source: Annual accounts of the European Union for years 2009 to 2015, excl. revenues from exchange transactions, i.e. financial income and other. Data for the year 2016 includes figures for the period ending 30 November 2016. www.eu.europa.eu/budget/figures/index_en.cfm, accessed 6 June 2017. 
The Impact of the Traditional Own Resources on the Budget of the European Union

The data presented in Table 2 show that the general budget for 2009-2011 showed an upward trend, while in 2015 and 2016 there was a slight decrease. Regardless of the period under review, the most budgeted resources in the structure of budget resources are the budget for GNI based contribution. VAT based contribution and traditional own resources tend to be stable in each year, however the fourth source of the budget revenue - other revenues differ each year, because of the content of this group, especially interests on late payments, fines and a surplus at the end of the year can be different each year.

In 2014 a High-Level Group on Own Resources has been established. Its aim is to examine how to make the system of financing the budget of the European system more transparent, fair, simple and democratically accountable. Its final report and recommendations were published on 17 January 2017 and was handed over to the presidents of the European Parliament, the Council, and the Commission. The Commission should now assess whether the reform of the own resources system is needed and appropriate.

\section{Traditional Own Resources}

The European Union is a customs union, which mean that there are common provisions on tariffs on trade within the customs area of the EU. There are no tariffs on trade within the European Union. The goods and services that arrive at the European customs area face a common external tariff irrespective of where they arrive at the European Union ${ }^{2}$. Other levies, for example, anti-dumping and countervailing duties are also collected together with ordinary customs duties (Reiwer-Kaliszewska, 2017: 421-434). During the years 1970-2008 duties on agricultural products were grouped separately, however, since 2008, they are identified with customs duties.

Traditional own resources are collected at the point that goods enter the European Union by the Member States. This revenue should then be transferred to the European Commission, even if they have not been actually collected by national customs authorities (Limbach, 2015). Due to the collection of the duties by the national customs authorities, the services at the central level remain minimal and regard mainly controls and oversight.

The Member States have the right to keep the collection costs $(20 \%$ of the collected amounts). This percentage was $10 \%$ during the years $1970-2000$, in 2001 it was increased to $25 \%$ and stayed at this level till 2014 .

2 The agricultural duties have been replaced by the customs duties in July 1995, however, some of them apply in the sugar market arrangement (van der Hoek, 2005: 269). 
Figure 3 Duties as Percentage of Total EU Revenues

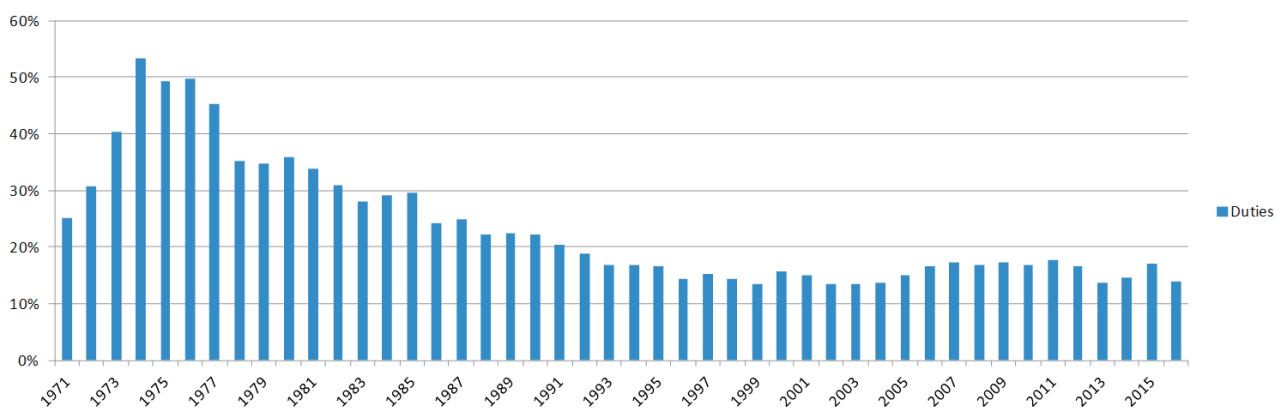

Source: Own calculation based on Annual accounts of the European Union for years 1971 to 2015, excl. revenues from exchange transactions, i.e. financial income and other. Data for the year 2016 includes figures for the period ending 30 November 2016. www.eu.europa.eu/budget/figures/index_ en.cfm, accessed 6 June 2017.

The impact of the traditional own resources has changed over the years. At the beginning of the customs union, they were the main resource of the EU budget. Between 1971 and 1975 it nearly doubled. Revenue from traditional own resources increased for about 10 years, until the end of the 1970s. From 1979 their impact decreased mainly due to introducing the VAT resource and GNI. Nowadays traditional own resources make up about $13 \%$ of the EU budget. The long-term trend in traditional own resources is downwards, due largely to the trade policy of the European Union and WTO trade liberalization.

Figure 4 Traditional Own Resources Contribution Per Capita by Country in 2015

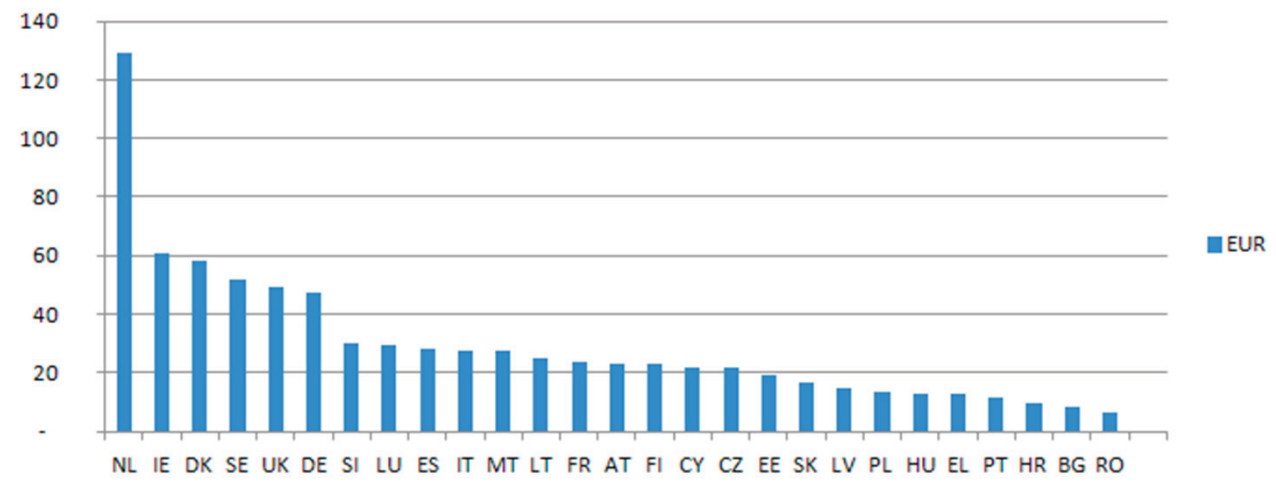

Source: Own calculation based on Annual accounts of the European Union for the year 2015, excl. revenues from exchange transactions, i.e. financial income and other. www.eu.europa.eu/budget/ figures/index_en.cfm, accessed 6 June 2017. 
The Impact of the Traditional Own Resources on the Budget of the European Union

Figure 5 Traditional Own Resources Contribution as Percentage of GNI by Country in 2015

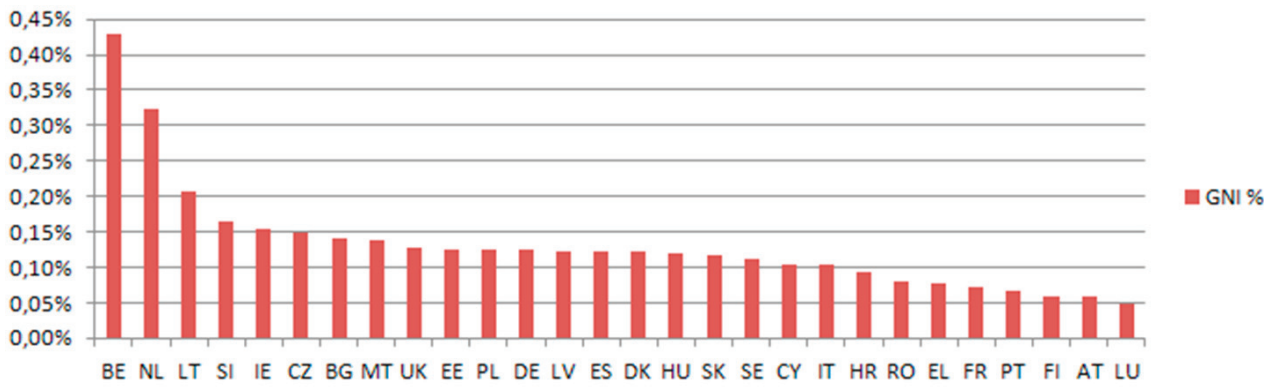

Source: Own calculation based on Annual accounts of the European Union for the year 2015, excl. revenues from exchange transactions, i.e. financial income and other. www.eu.europa.eu/budget/ figures/index_en.cfm, accessed 6 June 2017.

Figures 4 and 5 show traditional own resources per capita and as a percentage of GNI per country in 2015. What is not surprising countries with large ports, especially The Netherlands and Belgium, collect the largest amounts of duties. The landlocked countries, with few borders to non-EU countries, like Austria and Luxemburg collect relatively little in customs duties. The data presented in Table 5 show that there is little difference between richer and poorer countries regarding the amount they contribute as a share of their national income.

On 26 May 2014, the Council adopted a decision on the system of own resources of the European Union in the result of which changes were introduced to the system of the own resources for the period 2014-2020. The change concerning the traditional own resources is significant. Due to it, the proportion of traditional own resources retained by member states has been reduced from $25 \%$ to $20 \%$. In practice, the cost of collecting the duties has lately been far below this level. HM Revenue \& Customs estimated, that the average cost of collection of the taxes in the UK dropped from 0.66 pence per pound in 2010-2011 to 0.58 p for every pound collected in 2014-2015 (Annual Report and Accounts 2014-2015).

The reduction of the rate of the collection costs will obviously increase the amount of revenue that the European Union receives from traditional own resources and in result reduce the size of GNI-based contributions. The decision has entered into force on 1 October 2016, however, the rules apply retroactively as of 1 January 2014. This means, that the member states have to transfer to the European Union the extra $5 \%$ of the traditional own resources that have been retained as costs of collection. Their GNI based contributions will thus be lowered (Browne, Johnson, Philips, 2014: 11). With great probability, the net contribution of Belgium and The 
Netherlands, the countries collecting largest amounts of duties ${ }^{3}$, will increase, however, the other member states' overall contributions will stay unaffected. The reductions in the GNI-based payments to the EU will offset the increase in the proportion of tariffs paid over to the European Union Budget.

The High-Level Group on Own Resources in its Final Report and Recommendations published on 17 January 2017 has assessed the traditional own resources as a simple and transparent revenue (Future financing of the EU, Final report, and recommendations of the High-Level Group on Own Resources, 2016: 40). Due to the Final Report the current system of the traditional own resources is efficient, the national customs authorities agree to the rules and over years the system has not raised any major concerns in its implementation. The rules of the traditional own resources constitute the mostly undisputed baseline of the revenue of the European Union and seem satisfactory to all Member States.

\section{Conclusions}

The system of traditional own resources has undergone many changes over the years. In the beginning, in the seventies, it was the main EU budget revenue, however, with time the income concerned with traditional own resources were falling. The longterm trend in traditional resources is downwards, largely due to the trade policy of the European Union and the WTO trade liberalization. Traditional own resources now estimate about $13 \%$ of the EU budget remaining a non-negligible source of revenue. Thus the main hypothesis of this contribution that although the traditional own resources have a huge impact on the budget of the European Union the longterm trend is downwards has been confirmed.

In result of the recent change in traditional own resources, the proportion of traditional own resources retained by member states as collection costs has been reduced from $25 \%$ to $20 \%$. The aim of the changes was to increase the EU budget's revenue from traditional own resources, at the expense of funds retained by individual states. Although this solution is not beneficial for countries that have so far levied the largest duties as their remuneration drops, this would reduce the GNI share in the budget of the European Union.

The current system of the traditional own resources is simple, transparent and efficient and its rules seem satisfactory to all Member States. Over the years it has been the most undisputed revenue of the budget of the European Union.

The collection costs have often been considered as a "hidden" rebate that aim to reduce the contribution of the Netherlands to financing the budget of the European Union. 


\section{References}

Browne, J., Johnson, P., Philips, D.: The budget of the European Union: a guide, London: Institute for Fiscal Studies, 2014.

Limbach, K.: Uniformity of Customs Administration in the European Union, London: Bloomsbury, 2015.

Reiwer-Kaliszewska, A.: The Issue of Modernization of the XXI Century, in: Radvan, M., Gliniecka, J., Sowiński, T., Mrkyvka, P. (eds.): The Financial Law Towards Challenges of the XXI Century, Brno: Masaryk University, 2017.

Van der Hoek, M.P.: Handbook of Public Administration and Policy in the European Union, London: Routledge, 2005.

Annual accounts of the European Union for years 1971 to 2016. www.eu.europa.eu.

Future financing of the EU, Final report, and recommendations of the High-Level Group on Own Resources, 2016. www.ec.europa.eu.

HM Revenue \& Customs in its Annual Report and Accounts 2014-2015. www.gov.uk.

Multiannual Financial Framework - European Commission. www. ec.europa.eu. 